\title{
THE IMPACT OF THE DURATION OF LAWFUL RESIDENCE ON THE RIGHTS OF EUROPEAN UNION CITIZENS AND THEIR THIRD-COUNTRY FAMILY MEMBERS
}

\author{
Kathrin Hamenstädt*
}

\begin{abstract}
This contribution examines the role of the duration of lawful residence and the assessment of the facts of the individual case for the determination of the rights of (European) Union citizens and their family members by the Court of Justice of the European Union. While the Court initially embraced an approach which aimed at furthering and strengthening the rights of Union citizens, a conceptual shift has become visible over the last couple of years which seems to aim at limiting Union citizen's rights. This article seeks to shed light on the underlying rationale of the Court's judgments regarding Union citizens and their third-country family members by focusing on the application of the criterion of an individual assessment and the criterion of the duration of lawful residence respectively. To that end, it examines the Court's case law in four selected areas of European Union law: the protection against expulsion, the right of permanent residence, access to non-contributory cash benefits, and the right of residence of third-country family members of Union citizens upon return to the latter's Member State of nationality after having exercised free movement rights. It is submitted that the Court's application and interpretation of these criteria in the areas under scrutiny seems to be driven primarily by the aim to limit citizens' rights and not by the attainment of legal certainty which has been brought forward by the Court.
\end{abstract}

Keywords: EU citizenship; duration of residence; expulsion; social benefits; individual assessment

\section{§1. INTRODUCTION}

European Union citizenship, which was established by the Treaty of Maastricht in 1992, grants all nationals of the (currently 28) Member States of the European Union the 'right to move and

\footnotetext{
*DAAD lecturer in German law at King's College London.
} 
reside freely within the territory of the Member States'. ${ }^{1}$ This right is not unconditional, but rather 'subject to the limitations and conditions laid down in the Treaties and by the measures adopted to give them effect' ${ }^{2}$ The principle of non-discrimination that is enshrined, together with European Union citizenship in Part Two of the Treaty on the Functioning of the European Union (TFEU), provides that '[w]ithin the scope of application of the Treaties, and without prejudice to any special provisions contained therein, any discrimination on grounds of nationality shall be prohibited.'3 Throughout the 1990s and at the beginning of the millennium, the Court of Justice of the European Union (CJEU or Court) breathed life into the concept of European Union citizenship, often by recourse to the principle of non-discrimination. ${ }^{4}$

In the so-called 'constituent phase' ${ }^{5}$ of the case law on European Union citizenship, the CJEU held in its often quoted Grzelczyk judgment that 'Union citizenship is destined to be the fundamental status of nationals of the Member States, enabling those who find themselves in the same situation to enjoy the same treatment in law irrespective of their nationality, subject to such exceptions as are expressly provided for. ${ }^{6}$ This judgment is embedded in a series of other judgments such as Martínez Sala, ${ }^{7} \mathrm{D}^{\prime} \mathrm{Hoop},{ }^{8} \mathrm{MRAX},{ }^{9}$ and Baumbast and $R^{10}$ that did not only further the rights of European Union citizens (or Union citizens) but also the rights of their third-country family members. The equal treatment component of the Grzelczyk formula seems to have governed the development of Union citizenship also in the following so-called consolidation phase, ${ }^{11}$ in which the CJEU refined its case law and which is marked by the codification of the Court's case law in Directive 2004/38/EC. ${ }^{12}$

Over the last couple of years we have witnessed a conceptual shift in the CJEU's approach to Union citizenship. This shift is said to be 'characterised by an apparent retreat from the Court's

\footnotetext{
${ }^{1}$ Article 21 TFEU. This right is also enshrined in Article 45(1) of the Charter of Fundamental Rights of the European Union, [2012] OJ C 326/391.

${ }^{2}$ Article 21 TFEU.

${ }^{3}$ Article 18(1) TFEU.

${ }^{4}$ T. Kingreen, 'In love with the single market? Die EuGH-Entscheidung Alimanovic zum Ausschluss von Unionsbürgern von sozialen Grundsicherungsleistungen', Neue Zeitschrift für Verwaltungsrecht (2015), p. 1503. ${ }^{5}$ E. Spaventa, 'Earned Citizenship - understanding Union citizenship through its scope', in D. Kochenov (ed.), EU Citizenship and Federalism: the Role of Rights (Cambridge University Press, 2017), forthcoming.

${ }^{6}$ Case C-184/99 Grzelczyk, EU:C:2001:458, para. 31.

${ }^{7}$ Case C-85/96 Martínez Sala, EU:C:1998:217.

${ }^{8}$ Case C-224/98 D'Hoop, EU:C:2002:432.

${ }^{9}$ Case C-459/99 MRAX, EU:C:2002:461.

${ }^{10}$ Case C-413/99 Baumbast and R, EU:C:2002:493.

${ }^{11}$ E. Spaventa, in D. Kochenov (ed.), EU Citizenship and Federalism: the Role of Rights.

${ }^{12}$ Directive 2004/38/EC of 29 April 2004 on the right of citizens of the Union and their family members to move and reside freely within the territory of the Member States amending Regulation (EEC) No. 1612/68 and repealing Directives 64/221/EEC, 68/360/EEC, 72/194/EEC, 73/148/EEC, 75/34/EEC, 75/35/EEC, 90/364/EEC, 90/365/EEC and 93/96/EEC, [2004] OJ L 158/77. (the Citizenship Directive).
} 
original vision of citizenship in favour of a minimalist interpretation'. ${ }^{13}$ While it has been rightly pointed out that the CJEU does not 'hold a uniform concept of citizenship', ${ }^{14}$ its recent case law seems to support the assumption that there is a stronger focus on the last part of the Grzelczyk formula, namely the 'exceptions expressly provided for'. ${ }^{15}$ While the first two phases of the Court's case law have been characterized by integrationism ${ }^{16}$ or 'judicial activism' ${ }^{17}$ the current phase is said to exhibit a 'doctrinal conservatism'. ${ }^{18}$

This shift in the Court's case law shall be subsequently assessed with regard to four different areas of Union law. The analysis starts with the protection against expulsion (Section 2) where the duration of residence determines the level of protection granted against expulsion. It explores the Court's interpretation of the provisions regulating the protection against expulsion and critically discusses the Advocate General's approach. Second, the residence right of thirdcountry family members upon return to the Union citizen's home Member State is analysed (Section 3). This area is of particular interest as it is regulated neither by primary nor by secondary EU law and thereby leaves the Court some margin of discretion which allows a clearer view on the underlying rationale of its reasoning. The fourth section examines Union citizens' access to non-contributory cash benefits in the host Member State (Section 4.) The fifth section addresses the right to permanent residence (Section 5) which is acquired after five years of continuous and lawful residence. Finally, the protection against expulsion is revisited (Section 6), as the Court's interpretation of the right of permanent residence has implications for the protection against expulsion.

The analysis ${ }^{19}$ examines the effects of the Court's application of the criterion of the duration of lawful residence and the criterion of an individual assessment on the content of Union citizenship. Even though the duration of lawful residence is relevant in all categories under scrutiny, it is given special emphasis by the Court in cases concerning return (Section 3) and access to non-contributory cash benefits (Section 4), whereby the criteria listed in Article 7 of the Citizenship Directive play a central role. Second, the Court's use of the criterion of a case-

\footnotetext{
${ }^{13}$ E. Spaventa, in D. Kochenov (ed.), EU Citizenship and Federalism: the Role of Rights.

${ }^{14}$ D. Thym, 'The Elusive Limits of Solidarity: Residence Rights of and Social Benefits for Economically Inactive Union Citizens', 52 Common Market Law Review (2015), p. 33.

${ }^{15}$ See, among others, Case C-67/14 Alimanovic, EU:C:2015:597; Case C-333/13 Dano, EU:C:2014:2358; Case C-145/09 Tsakouridis, EU:C:2010:708; Case C-400/12 M.G., EU:C:2014:9.

${ }^{16}$ U. Šadl and M. Madsen, 'Did the Financial Crisis Change European Citizenship Law? An Analysis of Citizenship Rights Adjudication Before and After the Financial Crisis', 22 European Law Journal (2016), p. 41.

${ }^{17}$ D. Thym, 'When Union citizens turn into illegal migrants: the Dano case', 40 European Law Review (2015), p. 252.

18 Ibid.

${ }^{19}$ The focus rests primarily on the developments in the CJEU's case law after 2010.
} 
by-case assessment is scrutinized. It is submitted that this criterion is of minor or no relevance in the cases regarding return (Section 3) and access to social benefits (Section 4). In the cases concerning permanent residence (Section 5) and protection against expulsion (Section 6) the Court increasingly reverts to the notion of integration. Despite the fact that the Court seems to take the specific situation of the individual into account when referring to the notion of integration, the assessment of the facts of the case is limited to a specific aspect of the individual's personal circumstances. Furthermore, the notion of integration seems not to be used in the interest, but rather to the detriment of the individual. Finally, the findings are summarized, followed by a conclusion (Section 7).

\section{§2. PROTECTION AGAINST EXPULSION}

The protection against expulsion is linked to the duration of (lawful) residence and is mainly regulated by Articles 27 and 28 of the Citizenship Directive. These provisions specify the principles that must be observed when restricting Union citizens' fundamental freedoms on the grounds of public policy and public security and contain three main features. First, Article 27 of the Citizenship Directive stipulates the general principles, such as the principle of proportionality, and provides for limitations or 'prohibitions', as it bars expulsion decisions based on grounds of general prevention. ${ }^{20}$ The second feature is expressed by the elements that have to be taken into consideration when balancing the interests of the state against the interests of the foreigner. These elements are codified in Article 28(1) of the Citizenship Directive and comprise, among others, the 'family and economic situation, social and cultural integration into the host Member State and the extent of his/her links with the country of origin'. Third, Article 28 of the Citizenship Directive provides for a layered protection against expulsion depending on the duration of lawful residence. The longer the duration of the Union citizen's lawful residence, the stronger his or her protection against expulsion will be. Accordingly, three stages of protection can be distinguished in relation to the duration of residence: first, residence for up to five years, ${ }^{21}$ second, residence between five and ten years ${ }^{22}$ and, third, residence of at least ten years. ${ }^{23}$

\footnotetext{
${ }^{20}$ Article 27(2) of the Citizenship Directive.

${ }^{21}$ Article 27 and Article 28(1) of the Citizenship Directive.

${ }^{22}$ Article 27 and Article 28(1) and (2) of the Citizenship Directive.

${ }^{23}$ Article 27 and Article 28(1) and (3) of the Citizenship Directive.
} 
The three different stages of protection contained in Article 28 of the Citizenship Directive are based on the assumption that the longer the Union citizen resides on the territory of another Member State, the more this person and his or her family are integrated in that state. ${ }^{24}$ However, the protection against expulsion is not linked to the actual integration, but rather to the actual duration of residence. The incrementally stricter requirements for expelling a Union citizen contained in Article 28 of the Citizenship Directive evidences the fact that the EU legislature attaches an increasing weight to the interests of the Union citizen the longer (s)he resides in the host Member State.

The question of whether the level of protection against expulsion that is determined by the duration of residence can be undermined by the lack of the Union citizen's integration into the society of the host Member State was addressed by Advocate General Bot in his Opinion in the P.I. case. ${ }^{25}$ Even though there are a number of highly interesting cases concerning expulsion, ${ }^{26}$ the idea of taking the lack of integration into consideration when determining the level of protection against expulsion, was suggested for the first time by Advocate General Bot in the P.I. case. ${ }^{27}$ Case law regarding expulsion post-P.I. is addressed below (Section 6).

P.I. was an Italian national who resided for more than ten years in Germany. P.I. was subsequently convicted for sexually abusing of a minor, sexual coercion and rape - for which Germany sought to expel him. The Court was asked to assess whether the crimes committed by P.I. could constitute an imperative ground of public security in terms of Article 28(3)(a) of the Citizenship Directive.

In previous judgments that were not related to expulsion decisions, the Court held that public security refers to the Member State's internal and external security. ${ }^{28}$ The state's internal security covers the existence of the country's institutions, its essential public services and the survival of its inhabitants. ${ }^{29}$ The state's external security is closely intertwined with the security of the international community as a whole. Consequently, the question arose as to whether P.I.'s conduct qualified as a threat to public security.

\footnotetext{
${ }^{24}$ Recital 23 and Recital 24 of the Preamble to the Citizenship Directive.

${ }^{25}$ Opinion of Advocate General Bot in Case C-348/09 P.I., EU:C:2012:123.

${ }^{26}$ See for example: Case C-30/77 Bouchereau, EU:C:1977:172; Case C-348/96 Calfa, EU:C:1999:6; Case C482/01 and C-493/01 Orfanopoulos/Olivieri, EU:C:2004:262; Case C-145/09 Tsakouridis.

27 Opinion of Advocate General Bot in Case C-348/09 P.I., para. 49, 55, 56, 60.

${ }^{28}$ Case C-367/89 Aimé Richardt and Les Accessoires Scientifiques SNC, EU:C:1991:376, para. 22; Case C-83/94 Leifer, EU:C:1995:329, para. 26.

${ }^{29}$ Case C-72/83 Campus Oil Limited, EU:C:1984:256, para. 34.
} 
Advocate General Bot answered that question in the negative, but still denied P.I. protection against expulsion, by linking it to the notions of integration and social cohesion. In light of social cohesion it should be assessed, according to Bot, whether the individual is integrated into the society of the host Member State and referred to Recitals 23 and 24 of the Preamble to the Citizenship Directive, which both refer to the notion of integration. ${ }^{30}$ According to Bot, Article 28(3) of the Citizenship Directive contains a presumption of integration which is rebuttable. ${ }^{31}$ The EU legislature worked on the assumption that the duration of residence in the host Member State shows a degree of integration. After ten years of residence, the links between this citizen and the Member State 'are presumed to be close, to the point that they give that citizen the feeling that he is an integral part of the society of that State and that (...) is in order to promote social cohesion'. ${ }^{32}$ Yet, the integration of Union citizens is not only based on territorial and time factors, according to Advocate General Bot, but also on qualitative elements. ${ }^{33} \mathrm{He}$ denied the presence of these qualitative elements in cases where the individual's conduct 'constitutes a serious disturbance of public policy, shows a total lack of desire to integrate into the society". ${ }^{34}$ Consequently he concluded that P.I. could not enjoy the protection against expulsion provided for by the Citizenship Directive due to his lack of integration. Even although Advocate General Bot seems to focus on the facts of the individual case by taking the Union citizen's (here: P.I.'s) integration into account, his approach is nevertheless problematic.

Regarding the notion of integration referred to in the Preamble, it must be recalled that the Preamble to the Citizenship Directive is not legally binding. Both the Preamble and Article 28 of the Citizenship Directive abstain from requiring an integration of the Union citizen (or his or her third-country family member(s)) in order for him or her to enjoy protection against expulsion. Even though Article 28(1) of the Citizenship Directive refers to integration by obliging Member States to take the individual's social and cultural integration into account before issuing an expulsion decision, integration does not constitute a condition that the foreigner has to fulfil in order to enjoy the protection granted by Article 28(2) and (3) of the Citizenship Directive. ${ }^{35}$ The protection against expulsion is linked to the abstract and

\footnotetext{
${ }^{30}$ Opinion of Advocate General Bot in Case C-348/09 P.I., para. 49, 53-57.

${ }^{31}$ Ibid., para. 56.

${ }^{32}$ Ibid., para. 57.

${ }^{33}$ Ibid., para. 60.

${ }^{34}$ Ibid.

${ }^{35}$ Azoulai rightly points out that 'integration' was originally used as a qualifying criterion for protection, see L. Azoulai, 'The (Mis)Construction of the European Individual, Two Essays on Union Citizenship Law', EUI Department of Law Research Paper No. 2014/14 (2014), http://cadmus.eui.eu/bitstream/handle/1814/33293/LAW_WP \%202014_14.pdf?sequence=1\&isAllowed=y, p. 9.
} 
measurable duration of residence expressed in years and not to the notion of integration which is 'inherently open-ended' and 'an umbrella concept that can be given different meanings'. ${ }^{36}$

Advocate General Bot's interpretation of the notion of integration and his suggestion to make the protection against expulsion dependent upon a rebuttable presumption of integration constitutes a limitation of the protection granted to Union citizens and their family members, which has no legal basis in the Citizenship Directive. Neither the wording ${ }^{37}$ of the Directive nor its object and purpose support this approach.

Even though ultimately the Court did not follow the Advocate General's approach, it also weakened Union citizen's protection against expulsion, albeit by different means. Regarding the question of whether P.I.'s conduct was covered by the notion of 'imperative grounds of public security' the CJEU held that 'European law does not impose on Member States a uniform scale of values as regards the assessment of conduct which may be considered to be contrary to public security'. ${ }^{38}$ It further held that account must be had to Article 83(1) TFEU, which refers to sexual exploitation of children as one of the areas of particularly serious crimes with a crossborder dimension. ${ }^{39}$ In addition, the Court recalled the first Recital of the Preamble of Directive 2011/93, ${ }^{40}$ according to which sexual abuse and sexual exploitation of children constitute serious violations of fundamental rights. ${ }^{41}$ The Court did not decide whether P.I.'s conduct posed an imperative threat to public security and therefore left this issue to the Member States. It ruled 'that it is open to the Member State' to consider criminal offences as those referred to in Article 83(1) TFEU 'as constituting a particular serious threat to one of the fundamental interests of society, which might pose a direct threat to the calm and physical security of the population and thus be covered by the concept of "imperative grounds of public security" $(\ldots){ }^{4} \cdot{ }^{42}$

Despite their cruelty, the acts committed by P.I. were acts of general crime and constituted a breach of public policy, ${ }^{43}$ but they did not necessarily impact upon the internal or external

\footnotetext{
${ }^{36}$ D. Thym, 'Towards a Contextual Conception of Social Integration in EU Immigration Law. Comments on P \& $\mathrm{S}$ and K \& A', 18 European Journal of Migration and Law (2016), p. 106, 107. The notion of integration is further addressed below, (Section 5) and (Section 6).

${ }^{37}$ See also G. Anagnostaras, 'Enhanced protection of EU nationals against expulsion and the concept of internal public security: Comment on the P.I. case', 37 ELR (2012), S. 637.

${ }^{38}$ Case C-348/09 P.I., EU:C:2012:300, para. 21.

${ }^{39}$ Ibid., para. 25.

${ }^{40}$ Directive 2011/92/EU of the European Parliament and of the Council of 13 December 2011 on combating the sexual abuse and sexual exploitation of children and child pornography, and replacing Council Framework Decision 2004/68/JHA, [2011] OJ L 335/1.

${ }^{41}$ Ibid., para. 26, 27.

${ }^{42}$ Ibid., para. 28.

${ }^{43}$ See also, Opinion of Advocate General Bot in Case C-348/09 P.I., para. 60.
} 
security of the state and are therefore not covered by the Court's previous definition of public security. By ruling that it is for the Member States to consider whether the crimes committed by P.I. were covered by the concept of public security, the Court blurred the division between public policy and public security, ${ }^{44}$ granted more discretion to the Member States to expel Union citizens after ten years of lawful residence and thereby weakened the latter's position.

The Court did not follow the Advocate General's suggestion to make the protection against expulsion dependent upon a rebuttable presumption of integration. Even though the Court undermined the protection of Union citizens against expulsion, the level of protection in principle still depends on the duration of lawful residence. The protection incrementally increases the longer the Union citizen and his or her family member(s) reside on the territory of the host Member State and cannot be undermined or undone by the lack of integration on side of the individual. Yet, subsequent developments in the Court's case law, which are addressed below (Section 6), change this finding.

\section{§3. RESIDENCE RIGHTS OF THIRD-COUNTRY FAMILY MEMBERS UPON RETURN TO THE UNION CITIZEN'S HOME MEMBER STATE}

Cases in which Union citizens previously exercised free movement rights and then return to their Member State of nationality, wishing to be accompanied or joined by a third-country family member, were previously addressed by the Court in Singh ${ }^{45}$ and Eind. ${ }^{46}$ These cases took place in the pre-Citizenship Directive era, ${ }^{47}$ and the Court ruled that the third-country family member of a national of a Member State, who has availed himself of the right to freedom of movement and subsequently returned to the Member State of nationality, has a right of entry and residence according to Union law in the state of nationality of the Union citizen. ${ }^{48}$ The reason for not only granting a right of entry and residence to the third-country family member

\footnotetext{
${ }^{44}$ For further comments regarding the P.I. case, see G. Anagnostaras, 37 ELR (2012), p. 630, 634; L. Azoulai and S. Coutts, 'Restricting Union citizens' residence rights on grounds of public security. Where Union citizenship and the AFSJ meet: P.I.', 50 CMLRev. (2013), p. 568; T. Kostakopoulou and N. Ferreira, 'Testing Liberal Norms: The Public Policy and Public Security Derogations and the Cracks in European Union Citizenship', University of Warwick School of Law Legal Studies Research Paper No. 2013-18 (2013), http://sro.sussex.ac.uk/63227/1/Testing\%20Liberal\%20Norms\%20-\%20working\%20paper.pdf, p. 10; D. Kostakopoulou, 'When EU Citizens become Foreigners', 20 ELJ (2014), p. 458-460; D. Kochenov and B. Pirker, 'Deporting the Citizens within the European Union: A Counter-Intuitive Trend in Case C-348/09, P.I. v Oberbürgermeisterin der Stadt Remscheid', 19 Columbia Journal of European Law (2013), p. 388.

${ }^{45}$ Case C-370/90 Singh, EU:C:1992:296.

${ }^{46}$ Case C-291/05 Eind, EU:C:2007:771.

${ }^{47}$ Even though the Eind case was decided in 2007, the facts of the case date back to a time when Directive 2004/38/EC was not applicable.

${ }^{48}$ Case C-370/90 Singh, para. 25; Case C-291/05 Eind, para. 45.
} 
in the host Member State, but also in the home Member State of the Union citizen upon return, is based on the consideration that the denial of such a right could discourage Union citizens (in these cases workers) to avail themselves of the freedoms granted by the Treaty if they are not able to continue, 'on returning to his Member State of origin, a way of family life which may have come into being in the host Member State as a result of marriage or family reunification' ${ }^{49}$

Despite the fact that the Court addressed return situations in Eind and Singh, the Court's case law was not codified in the Citizenship Directive. This lack of codification gives the Court some margin of manoeuvre, and thereby makes this category particularly interesting, as it allows for a closer look at the underlying rationale of the Court's approach.

In March 2014, the CJEU was asked in $O . \& B .{ }^{50}$ whether the case law resulting from Singh and Eind was 'capable of being applied generally to family members of Union citizens who, having availed themselves of the rights conferred on them by Article 21(1) TFEU, resided in a Member State other than that of which they are nationals, before returning to the Member State of origin'. ${ }^{51}$ In essence, the real question was whether the case was covered by Union or national law. In this case, answering that question was of particular importance, as the rules on family reunification in national immigration law are sometimes stricter than the corresponding EU provisions. ${ }^{52}$ Union citizens who are unable to prove a link with Union law are sometimes subjected to stricter rules on family reunification than third-country nationals lawfully residing in the territory of the EU and covered by EU legislation. ${ }^{53}$

Noting that the Citizenship Directive does not cover the situation of return and taking Article 21(1) TFEU as a starting point, the Court ruled that the conditions of a derived right of residence for the family member of the Union citizen who returned to his Member State of nationality after having resided by virtue of his citizenship in another Member State, shall not be stricter than those requirements established by the Citizenship Directive which should be applied by analogy. ${ }^{54}$ Moreover the Court held that the Union citizen's residence in the host Member State must have been sufficiently genuine 'so as to enable that citizen to create or strengthen family

\footnotetext{
${ }^{49}$ See, Case C-291/05 Eind, para. 35 and 36; Case C-40/11 Iida, EU:C:2012:691, para. 70.

${ }^{50}$ Case C-456/12 O. \& B., EU:C:2014:135.

${ }^{51}$ Ibid., para. 48.

${ }^{52}$ For further information see, K. Groenendijk, 'Reverse Discrimination, Family Reunification and Union Citizens of Immigrant Origin’, in E. Guild, C. Gortázar Rotaeche and D. Kostakopoulou (eds.), The Reconceptualization of European Union Citizenship (Martinus Nijhoff, 2013), p. 176, 177; P. van Elsuwege and D. Kochenov, 'On the Limits of Judicial Intervention: EU Citizenship and Family Reunification Rights', 13 European Journal of Migration and Law (2011), p. 444, 456, 457.

${ }^{53}$ P. van Elsuwege and D. Kochenov, 13 EJML (2011), p. 444, 445.

${ }^{54}$ Case C-456/12 O. \& B., para. 50.
} 
life in that Member State'. ${ }^{55}$ For determining the genuineness of residence, the CJEU had recourse to Articles 6 and 7 of the Citizenship Directive which regulate the requirements for residence of up to three months (Article 6) and residence for more than three months up to five years (Article 7). It ruled that a 'Union citizen who exercises his rights under Article 6(1) of Directive 2004/38 does not intend to settle in the host Member State in a way which would be such as to create or strengthen family life in that Member State. ${ }^{56}$

On the other hand, an obstacle to leaving the Member State of which the worker is a national

may be created where the Union citizen intends to exercise his rights under Article 7(1) of Directive 2004/38. Residence in the host Member State pursuant to and in conformity with the conditions set out in Article 7(1) of that directive is, in principle, evidence of settling there and therefore of the Union citizen's genuine residence in the host Member State and goes hand in hand with creating and strengthening family life in that Member State. ${ }^{57}$

The judgment clarifies that not all cross-border situations are sufficient for granting the thirdcountry family member of a Union citizen a derived right of residence. Likewise, the mere intention to settle in another Member State without any manifestation of this intention is insufficient. According to the Court, residence of less than three months (Article 6 of the Citizenship Directive) cannot be regarded as sufficient evidence of the intention to settle. ${ }^{58}$ Only residence exceeding three months (Article 7 of the Citizenship Directive), which is linked to the fulfillment of further criteria, such as being a worker ${ }^{59}$ or having a comprehensive sickness insurance cover and sufficient means,${ }^{60}$ can be considered to be sufficient evidence of that intention. It is striking that despite the Court's referral to the Union citizen's 'intention to settle', ${ }^{61}$ the motives and the actual intention of the Union citizen when moving to another Member State do not seem be a consideration in the framework of assessment established by the Court. The Court seems to infer the intention to settle, and thereby a subjective element, from the objective criterion of the duration of residence and the fulfillment of the criteria listed in Article 7 of the Citizenship Directive only. It thereby adopts an approach to the notion of residence which differs from the interpretation established in Swaddling ${ }^{62}$ two decades earlier. In Swaddling, the Court ruled that in order to determine the Member State of residence ' $(. .$.

\footnotetext{
${ }^{55}$ Ibid., para. 51.

${ }^{56}$ Ibid., para. 52.

${ }^{57}$ Ibid., para. 53.

${ }^{58}$ Ibid., para. 52.

${ }^{59}$ Article 7(1)(a) of the Citizenship Directive.

${ }^{60}$ Article 7(1)(b) of the Citizenship Directive.

${ }^{61}$ Case C-456/12 O. \& B., para. 52, 53.

${ }^{62}$ Case C-90/97 Swaddling, EU:C:1999:96.
} 
account should be taken in particular of the (...) family situation; the reasons which have led him to move; the length and continuity of his residence; the fact (where this is the case) that he is in stable employment; and his intention as it appears from all the circumstances'.63 Paradoxically the notion of 'residence' as interpreted by the Court in Swaddling takes 'the intention as it appears from all the circumstances' and thereby adds a subjective element into the formula, whereas the Court's reference to the 'intention to settle' in $O$. \& $B$. seems to be limited to objective factors.

Moreover, the Court's reference to the Union citizen's 'intention' might evoke connotations of scenarios related to the abuse of Union law, especially since the Court briefly addressed this issue in $O . \& B .{ }^{64}$ The finding of an abuse requires, according to the Court referring to its judgment in Emsland-Stärke, an objective and a subjective element ${ }^{65}$ whereby the subjective element consists of 'the intention to obtain an advantage from the Community rules by creating artificially the conditions laid down for obtaining it' ${ }^{66}$ The question of an abuse of Union law and whether the intentions of the Union citizen can be subject to an assessment was raised in Akrich ${ }^{67}$ In Akrich, a Union citizen moved to another Member State in order to avoid national immigration legislation applying to her third-country family member, but had the intention of moving back to her home Member State at a later point. ${ }^{68}$ Reverting to the notion of 'intent' in a case concerning a return situation, coupled with a reference to an abuse of Union law is startling, not least because the Advocate General held that there was no evidence of fraud or an abuse of rights. ${ }^{69}$

In her Opinion, Advocate General Sharpston adopted a more nuanced approach. She had recourse to the Court's judgment in Swaddling and pointed out that the notion of residence is to be understood as the place 'where the habitual centre of interests are to be found and which should be established by the individual's intention as it appears from all the circumstances. ${ }^{, 70}$ Taking all the circumstances into account meant, according to Sharpston, that the decision must not be based 'on a single factor, but on a collection of criteria that together enable the individual's situation to be assessed and categorised as residence or non-residence'. ${ }^{71}$ Moreover

\footnotetext{
${ }^{63}$ Ibid., para. 29.

${ }^{64}$ Case C-456/12 O. \& B., para. 58.

${ }^{65}$ Ibid.; Case C-110/99 Emsland-Stärke, EU:C:2000:695, para. 52, 53.

${ }^{66}$ Case C-110/99 Emsland-Stärke, para. 53.

${ }^{67}$ Case C-109/01 Akrich, EU:C:2003:491.

${ }^{68}$ Ibid., para. 36.

${ }^{69}$ Opinion of Advocate General Sharpston in Case C-456/12 O. \& B., EU:C:2013:837, para. 42.

${ }^{70}$ Ibid., para. 100.

${ }^{71}$ Ibid.
} 
Sharpston submitted that the notion of residence is to be interpreted in light of the facts at issue, which include both objective and subjective elements. ${ }^{72}$ Sharpston held that the length of a Union citizen's stay in another Member State is a relevant criterion, but 'cannot be applied as an absolute threshold for deciding who has, or has not, exercised rights of residence' and that it is but one criterion that must be taken into account. ${ }^{73}$

For the Court, by contrast, the duration of the residence seemed to be crucial and decisive to the extent that it abstained from assessing the facts of the individual case. But what if the Union citizen concerned leaves the Member State of origin with the intention of settling in another Member State in order to establish or strengthen family life there with his or her third-country spouse? What if the Union citizen has to return to the Member State of nationality shortly after arriving in the host Member State, for example to take care of an elderly family member and therefore no longer fulfils the requirements established by Article 7 of the Citizenship Directive? Should the third-country family member be denied access to the Union citizen's country of origin? And should the Union citizen be forced to decide between staying with his or her spouse in the host Member State for at least three months or taking care of the elderly family member who needs his or her help in the Member State of origin?

This conflict demonstrates that reliance on the duration of lawful residence as the only relevant yardstick of assessment can result in harsh and disproportionate outcomes. Therefore, an assessment of the facts of the individual case which takes into account several factors, including the duration of lawful residence, would have been preferable. Given that this situation is not regulated by EU law and that the Court had some margin of discretion in answering the preliminary question, it is somewhat telling that the Court did not pursue this option.

Schoenmaekers and Hoogenboom rightly propose that a period of residence falling short of the three-month criterion must be evaluated on its merits. ${ }^{74}$ Their proposal is more likely to achieve balanced results as it takes a broader range of considerations into account and is to be favoured over the principle of proportionality.

Turning briefly to the Charter of Fundamental Rights (the Charter) it might be surprising at first sight that the Court did not mention Article 7 of the Charter (respect for private and family life)

\footnotetext{
72 Ibid., para. 101.

${ }^{73}$ Ibid., para. 111.

${ }^{74}$ S. Schoenmaekers and A. Hoogenboom, 'Singh and Carpenter Revisited: Some Progress but not Final Clarity Case C-456/12 O. v. Minister voor Immigratie, Integratie en Asiel, and Minister voor Immigratie, Integratie en Asiel v. B., Judgment of 12 March 2014, and Case C-457/12 S v. Minister voor Immigratie, Integratie en Asiel, and Minister voor Immigratie, Integratie en Asiel v. C., Judgment of 12 March 2014', 21 Maastricht Journal of European and Comparative Law (2014), p. 507.
} 
in its judgment, given that it assessed the intention to establish or strengthen family life in the host Member State. However, as this situation is not covered by the Citizenship Directive (or other directives or regulations), it could be argued that Member States are not implementing Union law within the meaning of Article 51(1) of the Charter with the consequence that the Charter is not applicable to them. On the other hand, it could be advanced that the Charter is applicable by analogy as the Court held that the conditions established by the Citizenship Directive should be applied by analogy. ${ }^{75}$ Yet, this approach did not seem to be a viable option for the Court.

In cases concerning return situations, which are not regulated by Union law, the Court opted to rely on the duration of lawful residence and the criteria contained in Article 7 of the Citizenship Directive without fully assessing the facts of the individual case. Despite its reference to the Union citizen's intention to settle, the actual intention to settle is insignificant and those individual circumstances that are not covered by Article 7 of the Citizenship Directive are disregarded. A similar approach was also chosen in the subsequent category.

\section{§4. NON-CONTRIBUTORY CASH BENEFITS AND THE COURT'S FOCUS ON ARTICLE 7 OF THE CITIZENSHIP DIRECTIVE}

Access to non-contributory cash benefits is not clearly regulated by the Citizenship Directive, ${ }^{76}$ which may well be accounted for by the political brisance of this topic. Despite great media attention and public discussion revolving around the topic misleadingly labelled as 'benefit tourism', the number of Union citizens actually seeking recourse to non-contributory cash benefits is low. ${ }^{77}$

The Court's case law on Union citizens' access to non-contributory cash benefits initially dealt with the question of whether the granting of benefits placed an 'unreasonable burden' on the social security system of the host Member State. The criterion of an 'unreasonable burden' is

\footnotetext{
${ }^{75}$ Case C-456/12 O. \& B., para. 50.

${ }^{76}$ P. Minderhoud, 'Directive 2004/38 and Access to Social Assistance Benefits', in E. Guild, C. Gortázar Rotaeche and D. Kostakopoulou (eds.), The Reconceptualization of European Union Citizenship, p. $210,211$.

${ }^{77}$ For Germany see, Bundesministerium des Innern, 'Abschlussbericht des Staatssekretärsausschusses zu

"Rechtsfragen und Herausforderungen bei der Inanspruchnahme der sozialen Sicherungssysteme durch Angehörige der EU-Mitgliedstaate", http://www.bmi.bund.de/SharedDocs/Downloads/DE/Broschueren/2014/abschlussbericht-armutsmigration.html, p. 30. In 2013, a total of 6.13 million persons living in shared households claimed benefits by way of basic provision under SGB II. EU citizens accounted for $4.7 \%$. Benefits by way of basic provision under SGB II were classified as 'special non-contributory cash benefits' within the meaning of Article 70(2) of Regulation No. 883/2004' by the referring German court in Dano. See, Case C-333/13 Dano, para. 47.
} 
based on Article 7(1)(b) of the Citizenship Directive and Recital 10 of the Preamble to the Directive, ${ }^{78}$ and has been regularly repeated by the Court. ${ }^{79}$

In Brey, a German national resident in Austria applied for a compensatory supplement in Austria as his German pension did not suffice. The competent Austrian authority refused the application since he did not have 'sufficient resources to establish his lawful residence in Austria' ${ }^{80}$ The Court clarified in its 2013 judgment that the receipt of 'social assistance is not sufficient to show that he constitutes an unreasonable burden on the social assistance system of the host Member State'. ${ }^{81}$ Moreover it rejected Austria's approach to automatically refusing the granting of benefits to economically inactive Union citizens. The Court further held that the competent authorities of the Member State must have regard to the principle of proportionality and must carry out an overall assessment of the specific burden which the granting of the benefit would place on the social assistance system as a whole and must take the 'personal circumstances characterising the individual situation of the person concerned' into account. ${ }^{82}$

Despite the fact that the Court's approach was rightly criticized for increasing legal uncertainty and confusion, ${ }^{83}$ the Court's reliance on the 'unreasonable burden' criterion has the advantage that it requires an individual assessment ${ }^{84}$ and necessitates a balancing process. The Court even provided criteria for this assessment, namely 'the amount and the regularity of the income which he receives; the fact that those factors have led those authorities to issue him with a certificate of residence; and the period during which the benefit applied for is likely to be granted to him'. ${ }^{85}$ Another feature which distinguishes the 2013 Brey case from subsequent

\footnotetext{
${ }^{78}$ Case C-140/12 Brey, EU:C:2013:565, para. 72, in which the Court held that Article 7(1)(b) of the Citizenship Directive is to be interpreted in terms of Recital 10 of the Preamble.

${ }^{79}$ See for example Case C-184/99 Grzelczyk, para. 44; Case C-158/07 Förster, EU:C:2008:630, para. 48 (maintenance cost of students); Case C-209/03 Bidar, EU:C:2005:169, para. 56 (maintenance cost of students). For further discussion regarding access to social assistance benefits and the relationship between Directive 2004/38/EC and Regulation No. 883/2004 in the pre-Brey era, see F. van Overmeiren, E. Eichenhofer and H. Verschueren, 'Social Security Coverage of Non-Active Persons Moving to Another Member State', in E. Guild, C. Gortázar Rotaeche and D. Kostakopoulou (eds.), The Reconceptualization of European Union Citizenship, p. 227-262.

${ }^{80}$ Case C-140/12 Brey, para. 17.

${ }^{81}$ Ibid., para. 75 .

${ }^{82}$ Ibid., para. 75-78. As to the problems of determining an unreasonable burden see, H. Verschueren, 'Free Movement or Benefit Tourism: The Unreasonable Burden of Brey', 16 European Journal of Migration and Law (2014), p. 171, 172; M. Dawson and B. de Witte, 'Welfare Policy and Social Inclusion', in A. Arnull and D. Chalmers (eds.), The Oxford Handbook of European Union Law (Oxford University Press, 2015), p. 970; P. Minderhoud, in E. Guild, C. Gortázar Rotaeche and D. Kostakopoulou (eds.), The Reconceptualization of European Union Citizenship, p. 218, 219, 223.

${ }^{83}$ H. Verschueren, 16 EJML (2014), p. 169; A. Iliopoulou-Penot, 'Deconstructing the former edifice of Union citizenship? The Alimanovic judgment', 53 Common Market Law Review (2016), p. 1026, who argues that the unreasonable burden test did not provide meaningful guidance to national authorities.

${ }^{84}$ Case C-140/12 Brey, para. 68, 69, 77, 78.

${ }^{85}$ Ibid., para. 78.
} 
cases concerning access to non-contributory cash benefits is the reference to (financial) 'solidarity between nationals of a host Member State and nationals of other Member States'. ${ }^{86}$ It was also in 2013 when Guild stated, based on her analysis of the relevant EU legislation, that 'the relation between social solidarity in the form of social benefits and citizenship of the EU is one of enhancement' ${ }^{87}$ However, the situation, at least with regard to the case law, changed shortly after the Brey judgment. In subsequent judgments regarding Union citizens' access to non-contributory cash benefits, the Court continued taking Article 7 of the Citizenship Directive as a starting point, but shifted from an individual assessment and a balancing process to an approach which relies mainly on the quantitative or measurable criteria contained in Article 7 of the Directive. In contrast to the Brey case, the notion of (financial) solidarity was no longer mentioned.

\section{A. THE DANO JUDGMENT}

The Dano case was decided in November 2014 and concerned the Romanian nationals Ms Dano and her son Florin, who resided in Germany for more than three months. Ms Dano did not work or seek work, nor was she ever employed throughout the duration of her stay in Germany. She and her son applied for non-contributory cash benefits according to the German Social Code II (Sozialgesetzbuch II) which was refused by the competent authorities. The referring German court asked the CJEU whether the relevant provisions of the TFEU and secondary legislation are to be interpreted as preventing national legislation which excludes Union citizens who are economically inactive from these benefits, while the Member State in question grants these benefits to its own nationals who are in the same situation. ${ }^{88}$

In its judgment, the CJEU had recourse to the prohibition of discrimination based on nationality ${ }^{89}$ laid down in Article 24(1) of the Citizenship Directive and Article 4 of Regulation No. 883/2004, ${ }^{90}$ and highlighted that Article 24(1) refers to 'all Union citizens residing on the basis of this Directive'. ${ }^{91}$ Given that Ms Dano resided for more than three months in the host Member State, Article 7 of the Directive was applicable to her. Yet, she did not fulfill the

\footnotetext{
${ }^{86}$ Ibid., para. 72.

${ }^{87}$ E. Guild, 'Does European Citizenship Blur the Borders of Solidarity', in E. Guild, C. Gortázar Rotaeche and

D. Kostakopoulou (eds.), The Reconceptualization of European Union Citizenship, p. 205.

${ }^{88}$ Case C-333/13 Dano, para. 45, 56.

${ }^{89}$ Ibid., para. 64.

${ }^{90}$ Regulation No. 883/2004/EC of the European Parliament and of the Council of 29 April 2004 on the coordination of social security systems, [2004] OJ L 166/1.

${ }^{91}$ Case C-333/13 Dano, para. 67, 68.
} 
conditions of Article 7(1) since she was neither a worker, nor did she have sufficient resources. Consequently, she did not have a right to reside on the basis of the Directive. Therefore, Article 24(1) in conjunction with Article 7(1) of the Citizenship Directive did not preclude national legislation which excluded her from access to these benefits. ${ }^{92}$

The focus of the Court's reasoning rested primarily on quantitative (duration of residence) and measurable (sufficient resources) criteria. Even though the Court referred to an individual assessment by holding that 'the financial situation of each person concerned should be examined specifically, (...) in order to determine whether he meets the condition of having sufficient resources to qualify for a right of residence under Article 7 (1) (b) of Directive $2004 / 38$, ${ }^{93}$ the individual assessment only extended to the individual's financial situation. ${ }^{94}$ Despite the fact that Ms Dano had lived for several years in Germany, where she gave birth to her son in 2009 and the fact that Ms Dano's sister provided for her and her son materially and accommodated them in her apartment,${ }^{95}$ qualitative criteria and fundamental rights did not seem to play a role in the Court's assessment.

Nic Shuibhne rightly points out that neither the notion of 'proportionality' nor the requirement of a proportionality assessment is mentioned..$^{96}$ The lack of attention given to the proportionality assessment is striking, especially when it is considered against the Citizenship Directive. The Directive establishes the requirement of conducting a balancing process in the context of recourse to social assistance, for example when determining whether the person becomes an unreasonable burden (Recital 16 of the Preamble to the Citizenship Directive) or whether a person has sufficient resources (Article 8(4) of the Citizenship Directive). Moreover, any automatism between recourse to social assistance and expulsion is prohibited (Article 14(3) of the Citizenship Directive). Even if it were argued that the Preamble is not legally binding and even if it were held that the mentioned articles are not decisive, as Ms Dano was not at risk of being expelled and it was clear that she did not have sufficient resources, these provisions demonstrate that the Citizenship Directive necessitates a balancing process. ${ }^{97}$ Ultimately, the principle of proportionality is a general principle of Union law.

\footnotetext{
92 Ibid., para. 82, 83.

${ }^{93}$ Ibid., para. 80.

${ }^{94}$ According to Thym, this reference is evidence of the individual approach adopted by the Court. See, D. Thym, 52 CMLRev. (2015), p. 31.

${ }^{95}$ Case C-333/13 Dano, para. 37.

${ }^{96}$ N. Nic Shuibhne, 'Limits rising, duties ascending: The changing legal shape of Union citizenship', 52 CMLRev. (2015), p. 913.

${ }^{97}$ See also, D. Thym, 52 CMLRev. (2015), p. 31.
} 
Next to the lack of a proportionality assessment the Court's statement regarding the inapplicability of the Charter is striking. The Court briefly addressed the issue of the Charter, since the referring national court raised this issue. It stated that neither Regulation No. 883/2004 nor the Citizenship Directive or any other secondary legislation regulate the conditions for the grant of these benefits that were in dispute. Accordingly, the Member States have 'the competence to determine the conditions for the grant of such benefits'. ${ }^{98}$ It concluded that it did not have 'jurisdiction to answer' this question as the Member States are not implementing Union law. ${ }^{99} \mathrm{Nic}$ Shuibhne observes that the Court fixated on the applicability of secondary EU law 'and did not cite its broader characterization of "implementing Union law". 100

\section{B. THE ALIMANOVIC CASE}

Despite the fact that Ms Alimanovic's residence right was based on Article 14 (4) (b) of the Citizenship Directive, the Alimanovic ${ }^{101}$ case contains insightful references to Article 7 of the Citizenship Directive, the duration and the lawfulness of residence and - since Ms Alimanovic pursued an economic activity in the host Member State - the required duration of the work relationship. Secondly, this case is highly relevant as the Court explicitly rejected an assessment of the facts of the individual case and a balancing process.

Ms Alimanovic and her older daughter, both Union citizens, were, in contrast to Ms Dano, previously economically active in the host Member State (Germany), before claiming subsistence allowances for the long-term unemployed as well as social allowances for the two minor children of Ms Alimanovic. These benefits, which were covered by Article 70 of Regulation No. 883/2004 ${ }^{102}$ and which are considered social assistance in terms of Article 24(2) of the Citizenship Directive, ${ }^{103}$ were granted for six months (1 December 2011 to 31 May 2012) after Ms Alimanovic and her daughter were employed as workers in Germany for eleven months. Had they worked for twelve months, they would have retained their status as workers pursuant to Article 7(3)(b) of the Citizenship Directive.

Lacking one month of employment, the CJEU drew on Article 7(3)(c) of the Citizenship Directive and noted that Ms Alimanovic and her daughter retained the status of workers for at

\footnotetext{
${ }^{98}$ Case C-333/13 Dano, para. 90.

${ }^{99}$ Ibid., para. 91, 92.

${ }^{100}$ N. Nic Shuibhne, 52 CMLRev. (2015), p. 914.

${ }^{101}$ Case C-67/14 Alimanovic.

102 Ibid., para. 43.

${ }^{103}$ Ibid., para. 44.
} 
least six months after their last employment had ended. ${ }^{104}$ Regarding the question of whether the refusal to grant Ms Alimanovic and her children benefits for the period of time exceeding these six months was compliant with Union law, the Court held that it must be determined 'whether the principle of equal treatment referred to in Article 24(1) (...) is applicable and, accordingly, whether the Union citizen concerned is lawfully resident on the territory of the host Member State. ${ }^{105}$ Regarding the question of whether the Union citizen is lawfully resident in the host Member State, the Court held that two provisions grant a residence right to job seekers. According to the first provision, Article 7(3)(c) of the Citizenship Directive, the status of worker is retained for at least six months after involuntary unemployment. Since this period had expired in the case of Ms. Alimanovic and her daughter, the second provision, Article 14(4)(b) of the Citizenship Directive, was decisive. The latter provision states that a Union citizen who entered the territory of the host Member State in order to seek employment there may not be expelled for as long as (s)he can provide evidence that (s)he is continuing to seek employment and has a genuine chance of being engaged. ${ }^{106}$

Given that Union citizens residing on the basis of the Citizenship Directive on the territory of another Member State in principle have a right to equal treatment with nationals of that Member State according to Article 24(1) of the Directive, Germany would have been obliged to grant Ms Alimanovic the requested benefits. Yet, Article 24(2) contains derogations to the principle of equal treatment. Accordingly, the Court ruled that Article 24(2) can be invoked 'in order not to grant that citizen the social assistance sought' given that Article 24(2) explicitly refers to Article 14(4)(b) of the Citizenship Directive. ${ }^{107}$ The CJEU distinguished the Alimanovic case from expulsion cases and from cases in which the Court referred to the 'unreasonable burden on the social assistance system of the Member State'. ${ }^{108}$ This distinction drawn by the Court is important, given that these two types of cases both require an assessment of the facts of the individual case and a balancing process between the interests of the individual and the interests of the state. In Alimanovic, the Court explicitly ruled that 'no such individual assessment is necessary in circumstances such as those at issue in the main proceedings'. ${ }^{109}$ The explanation provided by the Court as to why an individual assessment shall not be necessary is based on the gradual system as regards the retention of the status of 'worker', established by the Citizenship

\footnotetext{
104 Ibid., para. 53-55.

105 Ibid., para. 51.

${ }^{106}$ Article 14(4)(b) of the Citizenship Directive codified the criterion established in Case C-292/89 Antonissen, EU:C:1991:80, para. 21.

${ }^{107}$ Ibid., para. 57.

108 Ibid., para. 59.

${ }^{109}$ Ibid., para. 59.
} 
Directive. The Court stated that this gradual system seeks to safeguard the right of residence and access to social assistance and takes 'into consideration various factors characterising the individual situation of each applicant for social assistance and, in particular, the duration of the exercise of any economic activity'. ${ }^{110}$ The same reasoning was applied in García-Nieto to a Union citizen with less than three months of residence in the host Member State. ${ }^{111}$ However, the Court's reasoning can be criticized.

First, even if these provisions take 'various factors characterising the individual situation of each applicant' into consideration, they fall short of taking into account 'factors indicating possible close links' to the host Member State, ${ }^{112}$ in particular private and family life. Second, even if the respective provisions of the Citizenship Directive and the incremental system established by these provisions is in line with the principle of proportionality, the mere application of these provisions does not guarantee a proportionate outcome in each and every case. Statutory provisions are by their very nature abstract and general and cannot take all facts of the individual and concrete case into account. Therefore, it is imperative that a balancing process is conducted that takes individual circumstances into account.

Moreover the Court emphasized that the criterion referred to in Article 7(3)(c) of the Citizenship Directive, 'namely a period of six months after the cessation of employment during which the right to social assistance is retained' enables those 'concerned to know, without any ambiguity, what their rights and obligations are'. ${ }^{113}$ According to the Court, this criterion is 'consequently such as to guarantee a significant level of legal certainty and transparency in the context of the award of social assistance by way of basic provision, while complying with the principle of proportionality'. ${ }^{114}$

While the Court emphasized the advantages of its approach, it sacrificed the advantages of a balancing process between the interests of the state and the interests of the individual for the sake of legal certainty. It remains unclear how the six month period referred to in Article 7(3)(c) of the Citizenship Directive can comply with the principle of proportionality when it does not allow for other factors to be taken into account in order to determine whether a fair balance between the interests of the state and the interests of the individual has been struck. Even though the Court highlighted the benefits of legal certainty for the individual ('enabling those

\footnotetext{
${ }^{110}$ Ibid., para. 60.

${ }^{111}$ Case C-299/14 García-Nieto, EU:C:2016:114, para. 48.

112 A. Iliopoulou-Penot, 53 CMLRev. (2016), p. 1024.

${ }^{113}$ Case C-67/14 Alimanovic, para. 61.

${ }^{114}$ Ibid., para. 61.
} 
concerned to know, without ambiguity, what their rights and obligations are'), its approach seems to privilege the Member States to the detriment of the respective Union citizen. The individual's legal certainty would probably not be negatively impaired, if the Court had added the requirement of an individual assessment in case the Union citizen does not meet the requirements of Article 7(3)(c) of the Citizenship Directive. As Van Meerbeeck correctly remarks 'legal certainty should operate mainly for the benefit of the individual'. ${ }^{115}$

As to the applicability of the Charter, the Alimanovic case differs from the Dano case in one significant respect. While the Court held in Dano that the conditions for the granting of these benefits that were in dispute were not regulated by secondary legislation with the consequence that the Member State was not implementing Union law within the meaning of Article 51(1) of the Charter, Ms Alimanovic and her daughter were able to rely on Article 14(4)(b) of the Citizenship Directive and consequently they had a right of residence on the basis of this provision ${ }^{116}$ or rather its German implementing law. ${ }^{117}$ By applying the German provision that implemented Article 14(4)(b) of the Citizenship Directive, national authorities implemented Union law in terms of Article 51(1) of the Charter and were consequently bound by the Charter. The Charter in turn requires that an individual assessment and balancing process are conducted when it concerns the right to private and family life (Article 7 of the Charter). Given that Ms Alimanovic gave birth to her three children in Germany, it is startling that the CJEU did not address Article 7 of the Charter. Moreover, an application of the Charter would have given the Court the chance to elaborate on Article 34 of the Charter (which pertains to social security and social assistance).

Nic Shuibhne rightly opines that the "formerly central place of individual assessments is radically downgraded'. She acknowledges that a 'framework that requires a case-by-case assessments is far from perfect, especially from the perspectives of legal certainty and workability in practice'. ${ }^{118}$ In a similar line of argumentation, Spaventa points out with reference to the Förster ${ }^{119}$ and the $O . \& B .{ }^{120}$ cases that 'the case by case assessment unworkable for either Court or administrators - is left behind in favour of more predictable

\footnotetext{
115 J. Van Meerbeeck, 'The principle of legal certainty in the case-law of the European Court of Justice: from certainty to trust', 40 European Law Review (2016), p. 276.

${ }^{116}$ Case C-67/14 Alimanovic, para. 57. See further, S. Mantu and P. Minderhoud, 'Exploring the limits of social solidarity: welfare tourism and EU citizenship', 2 UNIO - EU law Journal (2016), p. 18.

$117 \S 2(2)$ no 1a Freedom of Movement Act/EU (Gesetz über die allgemeine Freizügigkeit von Unionsbürgern) which (back then) implemented Article 14(4)(b) of Directive 2004/38/EC.

${ }^{118}$ N. Nic Shuibhne, 52 CMLRev. (2015), p. 913.

${ }^{119}$ Case C-158/07 Förster.

${ }^{120}$ Case C-456/12 O. \& B.
} 
rights for economically inactive people'. ${ }^{121}$ On the other hand, Nic Shuibhne argues that an individual assessment 'does mediate the ambiguities built into the Directive'. ${ }^{122}$ Moreover, she rightly states 'that concerns about clarity and practical workability are absolutely valid; but they do call for clearer and better legislation'. ${ }^{123}$ Indeed, a case-by-case assessment is a source of insecurity. A casuistic approach makes it more difficult for national courts to bring their case law in line with the case law of the CJEU. Yet, insecurity regarding the outcome of the balancing process is an inherent feature of the principle of proportionality which in turn is a fundamental principle of Union law. Each and every balancing process requires that the facts of the individual case are carefully assessed and that the opposing interests are balanced against each other. The outcome of this process must be open, otherwise the principle of proportionality is reduced to absurdity. Moreover, this insecurity is acceptable as the criteria that have to be considered in the balancing process are either codified or derive from the CJEU's case law.

The Court's approach in cases regarding Union citizens' access to non-contributory cash benefits strongly relies on the duration and lawfulness of residence and the criteria established by Article 7 of the Citizenship Directive, and rejects an assessment of the facts of the individual case. Despite the Court's emphasis on legal certainty in order to enable the respective individual to know what his/her rights and obligations are, the chosen approach does not seem to follow the rationale of strengthening the Union citizen's rights. Rather it seems to primarily serve the interests of the Member States and to weaken Union citizen's rights.

\section{§5. THE RIGHT OF PERMANENT RESIDENCE}

Turning from the access to non-contributory cash benefits to the right of permanent residence, it is immediately salient that the requirements for obtaining the latter are clearly regulated by Article 16 of the Citizenship Directive. Article 16(1) provides that 'Union citizens who have resided legally for a continuous period of five years in the host Member State shall have the right of permanent residence there'. According to Article 16(2) of the Citizenship Directive, the right granted by Article 16(1) 'shall apply also to family members who are not nationals of a Member State and have legally resided with the Union citizen in the host Member State for a continuous period of five years'.

\footnotetext{
${ }^{121}$ E. Spaventa, in D. Kochenov (ed.), EU Citizenship and Federalism: the Role of Rights.

${ }^{122}$ N. Nic Shuibhne, 52 CMLRev. (2015), p. 913.

${ }^{123}$ Ibid., p. 919.
} 
In its 2011 Dias judgment, the Court already pointed to an integration objective which lies behind the acquisition of the right of permanent residence. It stated that 'Article 16(1) of Directive 2004/38 is based not only on territorial and time factors but also on qualitative elements, relating to the level of integration in the host Member State'. ${ }^{124}$

The Court followed the same rationale in its Onuekwere judgment where the acquisition of the right of permanent residence by a third-country family member of a Union citizen was at issue. The Court addressed the question of whether the time spent in prison can be taken into account for the calculation of the five-year period and the Court ultimately answered the question in the negative. Moreover it held that the continuity of residence was interrupted by the prison term. ${ }^{125}$ In reaching those conclusions, the Court stated that 'the right of permanent residence is a key element in promoting social cohesion and was provided for by that directive in order to strengthen the feeling of Union citizenship'. ${ }^{126}$ Furthermore it ruled that ' $[\mathrm{t}] \mathrm{he}$ EU legislature accordingly made the acquisition of the right of permanent residence (...) subject to the integration of the citizen of the Union in the host Member State'. ${ }^{127}$ A few paragraphs later the Court referred to the "the integration requirement which is a precondition of the acquisition of the right of permanent residence'. ${ }^{128}$

The Court's reference to the notion of social cohesion and its interpretation of the notion of integration deserves closer attention. Before focusing on the use of these notions in the Citizenship Directive and their interpretation by the CJEU, it should be noted that these concepts 'convey a set of normative values' and that they can be given different meanings. ${ }^{129}$ Groenendijk insightfully elaborates on three different perspectives on integration in EU migration law, ${ }^{130}$ of which two are of particular interest for this article. One perspective considers integration as an objective which is to be achieved by means of equal treatment of

\footnotetext{
${ }^{124}$ Case C-325/09 Dias, EU:C:2011:498, para. 64.

${ }^{125}$ Case C-378/12 Onuekwere, EU:C:2014:13. For comments on the case see S. Coutts, 'Union citizenship as probationary citizenship: Onuekwere', 52 Common Market Law Review (2015), p. 531-545.

${ }^{126}$ Case C-378/12 Onuekwere, para. 24.

127 Ibid.

${ }^{128}$ Ibid., para. 30.

${ }^{129}$ D. Thym, 18 EJML (2016), p. 106, 107.

${ }^{130}$ K. Groenendijk, 'Legal Concepts of Integration in EU Migration Law', 6 European Journal of Migration and Law (2004), p. 111-126.
} 
citizens and migrants, ${ }^{131}$ whereas the other perspective portrays integration as a condition enabling the migrant to have access to equal treatment or certain rights. ${ }^{132}$

Recital 17 of the Preamble to the Citizenship Directive refers to social cohesion by providing that the '[e]njoyment of permanent residence by Union citizens who have chosen to settle long term in the host Member State would strengthen the feeling of Union citizenship and is a key element in promoting social cohesion (...)'. In other words, the enjoyment of permanent residence strengthens the feeling of Union citizenship and is conducive to social cohesion in the host Member State. Hence, social cohesion is the aim to be strived for that shall be furthered by granting the right to permanent residence. This interpretation is supported by the wording of Recital 18 of the Preamble to Citizenship Directive which addresses integration. It provides that '[i]n order to be a genuine vehicle for integration into the society of the host Member State in which the Union citizen resides, the right of permanent residence, once obtained, should not be subject to any conditions.' This sentence also demonstrates that integration is to be achieved through the 'vehicle' of permanent residence and that the Union citizen's integration is not a precondition for obtaining the right to permanent residence. The Preamble to the Citizenship Directive seems to adhere to the first reading of the notion of integration whereby permanent residence is viewed as an instrument to achieve the aim of integration or social cohesion.

The Court's statements in Dias and Onuekwere demonstrate that it has adopted a different stance on these notions, that is also shared by Advocate General Bot, who considers the right of permanent residence as a reward for integration. ${ }^{133}$ Thym rightly observes that there is a 'conceptual shift away from equal rights as a means for integration, towards an output-oriented assessment that links citizens' rights to the degree of integration' ${ }^{134}$ However, by making the right of permanent residence conditional upon social cohesion or the Union citizen's integration into the society of the host Member State, the Court reverses the meaning of these notions ${ }^{135}$ that are employed by the Citizenship Directive. This shift has an impact on Union citizenship

\footnotetext{
${ }^{131}$ K. Groenendijk, 'Long-term immigrants and the Council of Europe', in E. Guild and P. Minderhoud (eds.), Security of Residence and Expulsion (Martinus Nijhoff, 2001), p. 7; D. Acosta, The Long-Term Resident Status as a Subsidiary Form of EU Citizenship, An Analysis of Directive 2003/109 (Martinus Nijhoff, 2011), p. 138; S. Coutts, 52 CMLRev. (2015), p. 537.

${ }^{132}$ K. Groenendijk, 6 EJML (2004), p. 113; D. Thym, 18 EJML (2016), p. 90.

${ }^{133}$ Opinion of Advocate General Bot in Case C-378/12 Onuekwere, EU:C:2013:640, para. 47.

${ }^{134}$ D. Thym, 52 CMLRev. (2015), p. 38.

${ }^{135}$ See also Azoulai who refers to the Court's judgment in Onuekwere and states that by making 'the acquisition of the right of permanent residence "subject to integration of the citizen of the Union in the host Member State", the Court changes the meaning of the concept of social cohesion', L.Azoulai, EUI Department of Law Research Paper No. 2014/14 (2014), p. 16.
} 
which no longer seems to be the fundamental status of nationals of the Member States, but rather an earned status ${ }^{136}$ or a probationary citizenship. ${ }^{137}$

Indeed, permanent residence requires a lawful, continuous residence and it may well be argued that imprisonment interrupts the period of lawful residence. Yet, it does not seem that the time spent in prison or imprisonment are decisive for the Court. ${ }^{138}$ The CJEU rather refers to the lack of integration which is demonstrated by the rejection of or 'non-compliance by the person concerned with the values expressed by the society of the host Member State in its criminal law'. 139

However, framing the requirement of lawful and continuous residence in the language of integration - whereby integration is understood as compliance with societal norms and values ignores other forms of integration (for example, economic integration, forging of family and personal relationships, and so on) and thereby does not allow for a comprehensive assessment of the facts of the individual case. Moreover, the Court's interpretation of the notion of integration differs from the notion found in the Preamble to the Citizenship Directive inasmuch as it considers integration as a condition for permanent residence and not as the aim which is to be achieved by granting the individual the right to permanent residence. It seems that the introduction of the criterion of integration into the assessment of whether the individual's residence is lawful and continuous aims at curtailing the right of Union citizens and their thirdcountry family members by preventing them from acquiring the right of permanent residence.

\section{§6. EXPULSION REVISITED}

On the same day the Court delivered its judgment in Onuekwere, ${ }^{140}$ the Court also ruled on the protection against expulsion in the M.G. case. ${ }^{141}$ Thematically, this judgment fits into the first section, but shall be addressed here as the Court seems to have shifted from its initial approach discussed in the first section to an approach which relies on the notion of integration.

\footnotetext{
${ }^{136}$ See, D. Kramer, 'Verdiend verblijf: EU-burgers en de sociale bijstand', Tijdschrift voor Europees en economisch recht (2016), p. 60 et seq.; E. Spaventa, in D. Kochenov (ed.), EU Citizenship and Federalism: the Role of Rights.

${ }^{137}$ S. Coutts, 52 CMLRev. (2015), p. 531.

${ }^{138}$ Ibid., p. 539.

${ }^{139}$ Case C-378/12 Onuekwere, para. 26, 31.

${ }^{140}$ See Section 5 above.

${ }^{141}$ Case C-400/12 M.G.
} 
The Portuguese national M.G. entered the United Kingdom in April 1998. She worked for almost one year and subsequently gave up work due to childbirth. She was supported financially by her husband until the couple's separation in 2006. Her three children were born in the UK and were placed in foster care following a report of non-accident-related injuries to one of the children. In August 2009, M.G. was convicted and sentenced to a 21 month prison term 'on one count of cruelty and three counts of assault by beating a person under 16 years'. ${ }^{142}$ On 8 July 2010, the Secretary of State ordered that M.G. be deported on grounds of public policy and public security. The referring English court asked the CJEU how the 10-year period of Article 28(3)(a) of the Citizenship Directive is to be calculated, whether the period spent in prison interrupts the period of residence, and whether it makes a difference that the Union citizen accrued ten years of residence prior to imprisonment.

The CJEU referred to its judgment in Tsakouridis ${ }^{143}$ and held that the ' 10 -year period must be calculated by counting back from the date of the decision ordering that person's expulsion'. ${ }^{144}$ By contrast, the period of time required for acquiring the right of permanent residence is calculated from the date when the person concerned commences lawful residence. ${ }^{145}$ Given that M.G. already lawfully resided in the UK ten years prior to her imprisonment, the method of calculating the 10-year period was crucial.

Moreover, the Court held that a period of imprisonment is capable of interrupting the continuity of the period of residence in terms of Article 28(3)(a) of the Citizenship Directive and 'affecting the decision regarding the grant of the enhanced protection provided for thereunder, even where the person concerned resided in the host Member State for 10 years prior to imprisonment. ${ }^{, 146}$ The 10-year residence 'may be taken into consideration as part of the overall assessment required in order to determine whether the integrating links previously forged with the Member State have been broken'. ${ }^{147}$

The Court already lowered the protection against expulsion granted to Union citizens who resided more than ten years in the host Member State in the previously discussed P.I. case, by blurring the line between public policy and public security. The judgment in M.G. marks a further step in this direction albeit by different means. In contrast to the P.I. case, where Advocate General Bot already argued that P.I. could not rely on the protection against expulsion

\footnotetext{
${ }^{142}$ Ibid., para. 13.

${ }^{143}$ Case C-145/09 Tsakouridis, para. 31.

${ }^{144}$ Case C-400/12 M.G., para. 23, 24.

145 Ibid., para. 24.

${ }^{146}$ Ibid., para. 38 .

${ }^{147}$ Ibid.
} 
given that he is not integrated, which at the time (2012) was not taken up by the Court, the Court's judgment in M.G. seems to revisit the Advocate General's original suggestion. When addressing the question of whether the period of imprisonment is capable of interrupting the continuity of residence, the Court pointed out that the protection against expulsion in the Citizenship Directive was 'based on the degree of integration of the persons concerned in the host Member State'. ${ }^{148}$ It emphasized that the 'degree of integration (...) is a vital consideration underpinning both the right of permanent residence and the system of protection against expulsion'. ${ }^{149}$

Making the protection against expulsion dependent on the individual's integration, in particular if it is conceived as a 'duty to integrate properly' ${ }^{150}$ is highly problematic. Union citizens who pose a threat to public policy or public security and are therefore subject to an expulsion decision are not usually considered to be 'properly' integrated within the host society, especially if integration is understood as compliance 'with the values expressed by the society of the host Member State in its criminal law'. ${ }^{151}$ Moreover, reliance on the criterion of integration in the context of expulsion is difficult to reconcile with the first sentence of Recital 23 of the Preamble to the Citizenship Directive. Recital 23 provides that '[e]xpulsion of Union citizens and their family members on grounds of public policy or public security is a measure that can seriously harm persons who, (...) have become genuinely integrated into the host Member State'. This sentence demonstrates that Union citizens, despite them having committed a crime and being subject to expulsion, can still be regarded as being integrated in the host society.

If the level of protection against an expulsion were not determined by the duration of residence, but by the integration of the individual, whereby integration is understood as compliance with the values of the host Member State expressed in its criminal law, the protection against expulsion would be reduced to absurdity as an individual who infringes criminal law and faces expulsion cannot be integrated.

Irrespective of the Court's reliance on the integration criterion, its judgment could be used as an instrument to annul the protection against expulsion granted after ten years of lawful residence altogether. The Court ruled that time spent in prison is capable of interrupting the continuity of the period of residence. Read in conjunction with the statement that the ten-year period must be calculated by counting back from the date of the decision ordering that person's

\footnotetext{
${ }^{148}$ Ibid., para. 30.

149 Ibid., para. 32.

${ }^{150}$ N. Nic Shuibhne, 52 CMLRev. (2015), p. 920.

${ }^{151}$ Case C-378/12 Onuekwere, para. 26, 31.
} 
expulsion, a Union citizen could, in principle, be stripped of the enhanced protection against expulsion by ordering a period of imprisonment preceding the actual decision to expel him or her. In such a case the Union citizen could not rely on ten years of lawful residence. Even lawful residence of more than ten years prior to imprisonment may not be sufficient to preserve the protection granted by Article 28(3) of the Citizenship Directive. The Court ruled that the ten years of lawful residence prior to imprisonment may be taken into consideration ${ }^{152}$ which means - argumentum e contrario- that they do not have to be taken into account. The Court's judgment thereby seems to mark a further stage in the process of undermining the rights of Union citizens.

In sum, the Court's reliance on the requirement of integration in order for the individual to benefit from protection against expulsion is problematic, in particular if integration is understood as compliance with the values expressed in criminal law of the host Member State or if it is conceived as an obligation to integrate properly. Individuals who have committed crimes could be excluded from the protection against expulsion provided for in the Citizenship Directive on the ground that they are not integrated, irrespective of the duration of their lawful residence. Moreover, the integration of the individual and the commission of a crime are not mutually exclusive as demonstrated by Recital 23 of the Preamble to the Citizenship Directive. Finally, the notion of integration is open to interpretation and consequently it is not necessarily conducive for creating legal certainty.

\section{§7. SUMMARY AND CONCLUSION}

Over the course of the last few years, we have witnessed a phase of stagnation in the Court's case law that exhibits elements of retreat from its 'original vision' of Union citizenship. ${ }^{153}$ The Court has adopted an interpretation which is detrimental to Union citizens and which goes beyond the approaches suggested by national governments. ${ }^{154}$

The present analysis focused on the CJEU's case law in four areas. It started with the protection against expulsion which is important as the determination of the level of protection against expulsion depends on the duration of lawful residence. The protection against expulsion increases the longer the Union citizen resides in the host Member State. The protection granted

\footnotetext{
${ }^{152}$ Case C-400/12 M.G., para. 37.

${ }^{153}$ E. Spaventa, in D. Kochenov (ed.), EU Citizenship and Federalism: the Role of Rights.

${ }^{154}$ See for further information, Opinion of Advocate General Bot in Case C-378/12 Onuekwere, para. 60.
} 
to Union citizens due to the duration of their lawful residence could initially not be undermined by the lack of integration of the Union citizen in the society of the host Member State.

The second group of cases concerned the right of residence of third-country family members of Union citizens upon return to the latter's Member State of nationality, a scenario which is not regulated by Union law. The Court relied on the duration of lawful residence in the host Member State required by Article 7 of the Citizenship Directive. Reliance on the criteria of Article 7 of the Citizenship Directive can also be observed in the third group of cases concerning access to non-contributory cash benefits. In the third group, the focus on the clear criteria of Article 7 of the Citizenship Directive was motivated by legal certainty and legal security.

The approach adopted by the Court in the second and third group of cases falls short of taking the facts of the individual case into account. In Alimanovic, the Court even ruled that an individual assessment is not necessary given that the gradual system established by the Citizenship Directive with regard to the status of 'worker' takes various factors into consideration which characterize the situation of the individual.

However, an abstract and general provision cannot replace a balancing process which takes the facts of the individual case into account. Conducting an individual assessment and a balancing process between the interests of the individual and the interests of the state would not only serve the principle of proportionality, it would also accommodate the Charter of Fundamental Rights and would be an apt instrument to fill the gaps left by the Court's approach.

Yet, from the Court's point of view there does not seem to be a gap. The approach adopted in the second and third group of cases rather fits neatly in an overall system of interpretation, which seems to rely on the duration of lawful residence, in particular the criteria of Article 7 of the Citizenship Directive, if this is expedient to curtail Union citizens' rights, whereas the opposite approach, which nevertheless pursues the same objective, is adopted in the fourth and the fifth group of cases. The fourth and fifth group of cases concerned the right of permanent residence which is, according to Article 16(1) of the Citizenship Directive, obtained after five years of lawful and continuous residence, and the protection against expulsion which increases the longer the Union citizen resides in the host Member State. Compared to the second or third group of cases where legal certainty was to be achieved by reference to the quantitative and measurable criteria contained in Article 7 of the Citizenship Directive, the fourth and fifth group of cases should, from the Court's point of reasoning, not be subject to any objection given that they contain clear criteria which enhance legal certainty. 
However, viewed through the lens of the rationale to limit the rights of Union citizens, the Court opted to apply the criterion of integration in order to limit the scope of application of these rights. The fact that legal clarity and legal certainty are not necessarily furthered by making the application of these rights conditional upon the fulfillment of the open-ended notion of integration did not seem to prevent the Court from stating that integration is a vital consideration 'underpinning both the right of permanent residence and the system of protection against expulsion'. ${ }^{155}$ The Charter of Fundamental Rights did not play a role in the judgments addressed above, despite the fact that it could have been applied, at the very least, in the Alimanovic case.

The shift in the Court's case law becomes apparent in the minimalist interpretation of Union citizens' rights and manifests itself in different ways. The Court's use and interpretation of the criterion of the duration of lawful residence and assessment of the facts of the individual case is only one example. It was demonstrated that the Court's claim to further legal certainty, which was advanced in the third category of cases, is rebutted by the legal insecurity caused in the fourth and fifth category of cases by the Court's reference to the open-ended criterion of integration. Despite the fact that the Court adopted diverging approaches in these different categories of cases, the underlying rational of these judgments does not seem to be the strengthening of legal certainty, but rather the limitation of Union citizens' rights.

${ }^{155}$ Case C-400/12 M.G., para. 32. 